\section{Hans Jonas: da bioética à ética responsabilidade}

\section{Sganzerla, Anor}

PUCPR. E-mail: anor.sganzerla@gmail.com

\section{Xavier, Bruno Rosário}

PUCPR: E-mail: brunohrxavier@gmail.com

PALAVRAS-CHAVE: Hans Jonas; Bioética; Ética; Responsabilidade

Introdução: O convite para ministrar uma conferência pela American academy of arts and sciences, de Boston (1967) intitulada Reflexões filosóficas sobre os experimentos com sujeitos humanos deu grande notoriedade ao pensamento de Hans Jonas. Esse reconhecimento, no entanto, não esteve isento de críticas, principalmente por parte dos médicos, em relação à posição do filósofo quanto à retirada de órgãos dos pacientes em estado de morte cerebral definido pela comissão. A conferência e sua posterior publicação também promoveu uma significativa mudança na forma de Jonas fazer sua filosofia. Passou a fazer filosofia prática. A oposição de Jonas em relação à algumas teses defendidas por um grupo de médicos, do Centro médico da universidade da Califórnia, fizeram com que o próprio Jonas fosse convidado por esses médicos a acompanhá-los em seu trabalho de transplante de órgãos no centro cirúrgico. Afirma Jonas que a experiência foi extraordinária. Método: Essa pesquisa será essencialmente teórica filosófica, utilizando-se para tanto dos textos clássicos do autor. Resultados: No entanto, o filósofo, apesar de reconhecer esforço e a ética desses profissionais em sua atividade, manteve intacta a sua posição de que somente os interesses do paciente é que devem ser levados em conta, e não os possíveis benefícios que possam trazer a terceiros no caso da doação e do transplante de órgãos. Esse reconhecimento público de Jonas a partir da conferência e das atividades no centro cirúrgico, fez com que o filósofo fosse convidado a trabalhar no renomado centro de pesquisas médicas norte-americano intitulado Hasting Center. No ano de 1969 o centro criou o Instituto de bioética no qual Jonas desempenhou um papel importante, e sua atuação por mais de vinte anos rendeu-lhe o título de sócio-fundador do centro. A distinta formação acadêmica de seus integrantes dava ao grupo um forte caráter interdisciplinar. Conclusões: O trabalho realizado no Hasting Center, direcionou o pensamento de Jonas para os problemas éticos da tecnologia moderna, e da necessidade de uma ética da responsabilidade para orientar o progresso da tecnociência. Desse modo, é a partir da reflexão sobre temas de bioética, como a ameaça a vida e a dignidade humana promovidas pela técnica, a responsabilidade nos experimentos dos seres humanos, a clonagem de humanos, o direito de viver e o direito de morrer, o transplante de órgãos, a eugenia genética, o melhoramento humano, morte cerebral, técnicas de adiamento da morte, os avanços das biotecnologias que Jonas fundamento a sua ética da responsabilidade.

\section{REFERÊNCIAS}

[1] JONAS, H. O princípio responsabilidade: ensaios de uma ética para a civilização tecnológica. RJ: Contraponto/Editora da PUC-Rio, 2006.

[2] JONAS, H. Técnica, medicina e ética: sobre a prática do princípio responsabilidade. SP: Editora Paulus, 2013.

]3] JONAS, H. Ensaios filosóficos: da crença antiga ao homem tecnológico. SP: Paulus, 2017. 